\title{
The status of Te Ātiawa histories of place in Port Nicholson Block (Wellington, Hutt Valley) secondary schools: Some research findings
}

\author{
Richard Manning
}

\begin{abstract}
This article outlines the research methodology and some key findings from my doctoral research project (Manning, 2008), which examined the status of Te Ātiawa histories of place in Port Nicholson Block secondary schools' history classes. It describes the research participants' experiences of cultural continuity and discontinuity experienced in familial and secondary school settings when learning about the past. It also describes the participants' history topic preferences, and their perceptions of the benefits and barriers in relation to a potential placebased education partnership between local Te Âtiawa people and the participating schools. Two metaphors are developed to help conclude this article. I conclude that New Zealand history teachers often deliver an enacted curriculum, contradicting the objectives of the official New Zealand curriculum and the principles of the Treaty of Waitangi.
\end{abstract}

\section{Introduction}

This article draws upon doctoral research (Manning, 2008) to discuss the status of Te Ātiawa tribal knowledge in 24 Port Nicholson Block (Wellington and Hutt Valley) secondary schools' history classes. ${ }^{1}$ The article firstly considers the potential benefits of adopting a critical pedagogy of place and place-based education (PBE). It then discusses my research findings in relation to the research participants' (a) experiences of cultural continuity and discontinuity experienced in their familial and secondary school settings when learning about the past; (b) preferences in relation to history topics; and (c) perceptions regarding the benefits of, and barriers to, a potential PBE partnership between local Te Ātiawa people and the participating schools. 
In conclusion, tuna (eels) inhabiting the Waitangi Stream, now piped below the busy streets of central Wellington city, provide a metaphor for the argument that Te Ātiawa and other tribal histories should be resurfaced in Port Nicholson Block secondary schools, much as lower reaches of that stream have been resurfaced-following careful consultation. An hīnaki (eel trap) metaphor is also applied to describe the barriers obstructing teacher participants from engaging in a PBE partnership with Te Ātiawa. These barriers are then related to the Ministry of Education's The New Zealand Curriculum (2007), the principles of the Treaty of Waitangi (1840) and the findings of the Waitangi Tribunal (2004, p. 740).

\section{The research objectives and methodology in their local (historical) settings}

My doctoral research was conducted following the release of the Waitangi Tribunal's (2003) Te Whanganui a Tara me ōna Takiwā report which investigated the Crown's alienation of tribal lands and other resources in the Port Nicholson Block area. ${ }^{2}$ My research was not designed to critique the tribunal's report, or to comment on the role of the Wellington Tenths Trust $^{3}$ in the presentation of claims central to that report. Instead, it explored how participants viewed the teaching of local, Māori, environmental and New Zealand histories, particularly in relation to their own life experiences of learning about past and place.

Nine Te Âtiawa adults selected from a pool of potential "expert" interviewees nominated by the Wellington Tenths Trust participated in this research. Nine senior history teachers (eight Pākehā), who volunteered to take part in this research with the permission of their employers, also participated. Both groups of participants were invited to individually reflect upon cultural continuities and discontinuities they experienced in relation to how local, New Zealand and Māori histories were taught in their familial and secondary school settings. They were also asked what topics they felt should be taught in Port Nicholson Block secondary schools today. In addition, a survey was developed to identify topics taught in Port Nicholson Block schools in 2005. These results were related to a survey conducted that same year by the New Zealand History Teachers' Association (NZHTA). The NZHTA survey produced 126 
responses to questions regarding topics taught at NCEA levels 1-2, while 121 respondents responded to a question about level 3 topics. Generally speaking, my survey findings support those of the NZHTA. Both surveys indicate that Māori content was often sidestepped, and this has major political implications.

\section{The need for a critical pedagogy of place}

The Waitangi Tribunal, in its (2004) report on the Tūranganui a Kiwa (Gisborne) claims, called for New Zealanders to possess a greater "consciousness" of "historical memory of place". It concluded (p. 740) that:

We cannot help but think that the unsettled state of relations between Māori and Pākehā in this country is in part due to the fact that these stories are remembered only by tangata whenua and a few historians who specialise in New Zealand history. While only one side remembers the suffering of the past, dialogue will always be difficult. One side commences the dialogue with anger and the other side has no idea why. Reconciliation cannot be achieved by this means. Thus it seems no more than common sense that if stories such as these from Tūranga were more widely known in the community, particularly local communities more directly affected, the need to heal the wounds of the past before moving forward would be better understood by all.

I suspect the "twin goals" of "decolonisation" and "reinhabitation", underpinning a critical pedagogy of place, may assist New Zealand secondary schools to respond meaningfully to the tribunal's conclusion. As Gruenewald (2003, p. 9) proposed:

In many ways decolonization describes the underside of reinhabitation; it may not be possible without decolonization. If reinhabitation involves learning to live well socially and ecologically in places that have been disrupted and injured, decolonization involves learning to recognize disruption and injury and to address their causes. ${ }^{4}$ From an educational perspective, it means unlearning much of what dominant [e.g., Pākehā] culture and schooling teaches, and learning more socially just and ecologically sustainable ways of being in the world. 
This is not to suggest that a critical pedagogy of place constitutes a pedagogical "silver bullet" that will remedy the New Zealand secondary school system's failings, particularly those affecting Māori. Rather, given my research findings and the Waitangi Tribunal's concerns (2004, p. 740), I simply wish to encourage the adoption of critical pedagogies of place and PBE models that, as Gruenewald and Smith (2007, p. xxi) suggest, might challenge:

... conventional notions of diversity within education, of multiculturalism or culturally responsive teaching, which too often take for granted the legitimacy and value of an education that disregards places in all their particularity and uniqueness. Critical issues of race, class, gender and other aspects of culture can become abstractions unless these issues are grounded in concrete experience, experience that always takes place somewhere. Place-consciousness toward diversity and multiculturalism means reconnecting these themes with rooted experience of people in their total environments, including the ecological ... This rooted experience ... must also include consciousness of historical memory of a place, and the traditions that emerged there, whether these have been disrupted or conserved.

As Zucker (as cited in Sobel, 2004, p. iii) recognised, PBE is distinguishable by the fact that it actively challenges conventional notions of education by requiring students to ask seemingly "simple" questions like "Where am I?" "What is the nature of this place?" "What sustains this community?" Zucker (as cited in Sobel, 2004, p. iii) emphasises that it requires nothing less than a "re-storying process" whereby students "are required to respond creatively to stories of their home-ground so that, in time, they are able to position themselves, imaginatively and actually within the continuum of nature and culture in that place. Thus students are required to become 'part of the community', not 'passive observers' of it."

\section{Research findings}

\section{Cultural continuities and discontinuities}

The Te Ātiawa interviewees experienced many cultural discontinuities between their respective secondary school and familial settings. One 
interviewee (Manning, 2008, p. 99) encapsulated their experiences when he said:

At school, the histories were quite limited ... Of the local Wellington personalities, only Te Rauparaha [a famous Ngāti Toa chief] had featured, but he was stereotyped as a bloodthirsty and cunning chief who held sway over large parts of the country. There was little taught of how the people [iwi] lived or how they subsisted ... However, from my whānau [family] I learnt about how and where people lived, what were important places and who were the people of those places.

By contrast, the teachers identified far fewer cultural discontinuities. While the responses of the Te Âtiawa interviewees were generally passionate and critical in tone, the teachers' responses appeared dispassionate and largely unaware of the political implications of the continuities they did experience. Further, the Te Ātiawa participants frequently complained about the racial (i.e., "anti-Māori") biases of their teachers, whereas eight of the nine teacher participants did not. ${ }^{5}$

Of particular note is that, though all of the Te Ātiawa participants had family members who used their local landscapes, flora and fauna to teach them about the past, most teachers (seven) did not. ${ }^{6}$ Significantly, none of the 18 research participants recalled encountering a teacher of history, or social studies, who had used flora and fauna to teach them about the past. The secondary schools the participants attended had disconnected them from the lands, flora and fauna surrounding their schools, not to mention the tangata whenua (indigenous people of those lands). Moreover, the histories they were taught recall Cajete's (1999, pp. 189-206) description of a typically "biophobic" and anthropocentric "Western" curriculum.

Cajete proposed (p. 190) that "indigenous education", alternatively, is:

$\ldots$ an education that focuses on the core aspects of human biophilia. It is an education about community and spirit whose components include: the recognition of interdependence; the use of linguistic metaphors, art and myth; a focus on local knowledge and direct experience with nature; orientation to place; and the discovery of 'face, heart and foundation', in the context of key social and environmental relationships. 
Two Alaskan academics, Oscar Kawagley and Ray Barnhardt (1999, p. 117), similarly, suggested that:

Students in indigenous societies around the world have, for the most part, demonstrated a distinct lack of enthusiasm for the experience of schooling in its conventional form - an aversion that is most often attributable to an alien school culture, rather than any lack of innate intelligence, ingenuity, or problem-solving skills on the part of the students. The curricula, teaching methodologies, and often the teacher training associated with schooling are based on a worldview that does not always recognize or appreciate indigenous notions of an interdependent universe and the importance of place in their societies.

These observations are telling when one considers the Te Âtiawa interviewees' experiences of cultural discontinuities between home and school environs, and their preferences for "holistic" approaches to teaching.

\section{Topic preferences}

The Te Ātiawa interviewees preferred "holistic" (integrated) curriculum activities that would enable local students to critically explore the role of the natural world in shaping alternative constructs of history. They felt that Māori history should not revolve exclusively around interactions with Pākehā and that teachers should encourage students to draw upon local tribes' particularistic local knowledge to critique universalistic Pākehā grand narratives of New Zealand history. Māori content, however, was generally avoided in the schools surveyed by this writer and the NZHTA in 2005. I encountered very few history teachers who could name any of the local claimant groupings, or who knew that the tribunal's (2003) Te Whanganui a Tara me ōna Takiwā report even existed. The following comment, made by one of the teachers (Manning, 2008, p. 240), denotes the extent of the disconnectedness from local tribes that most (eight) teachers felt:

For me, what I know about the local Māori community comes from the 10 minutes of Māori news on National Radio between 6.25 and $6.35 \mathrm{pm}$, or it's whatever happens on TV3 News. Otherwise, I've got no contact with anyone Māori at all. Probably the only 'flesh and blood' [local] Māori person that I've ever had any contact with, since arriving here in 
Wellington, was a colleague of my wife, who worked at the Ministry of Education.

Very few history topics covered Māori content, and those that did incorporated little, if any, local tribal content. A total of 29 percent of the Port Nicholson Block schools I surveyed offered the NCEA level 1 topic Māori and Pākehā (1912-1980). Similarly, the NZHTA survey reported that 23 percent of schools taught this topic. Although four new level 1 "Māori history" topics were introduced by the Ministry of Education (2001), the NZHTA found that only 3 percent of schools offered the new topic The Place of the Tiriti [Treaty] of Waitangi in New Zealand Society (1975-1985). None of the other new Māori topics were taught by the schools it surveyed. ${ }^{7}$ No Port Nicholson Block school offered any of the new "Māori" topics. Māori content also appeared to be unpopular at NCEA level 2.

Though the long-standing Māori Leadership in the Nineteenth Century topic was identified by both surveys as being the most popular New Zealand topic, the NZHTA's survey revealed that 93 percent of schools didn't offer this topic, and my survey showed that 87 percent of Port Nicholson Block schools didn't offer it. ${ }^{8}$ None of the schools surveyed by the NZHTA or myself taught the new "Māori history" topics that the Ministry (2002) had added to the appendices to the level 2 history achievement standards. ${ }^{9}$ In relation to NCEA level 3, the NZHTA survey (2005) indicated that 70 (58 percent) of the schools offered the TudorStuart England (1557-1665) topic. Forty-eight (40 percent) of the schools it surveyed offered the New Zealand in the Nineteenth Century topic, while three ( 8 percent) of the schools gave students a "choice of topic".

My survey found that 10 (46 percent) of the Port Nicholson Block schools surveyed taught the Tudor-Stuart topic, and an identical number taught the New Zealand in the Nineteenth Century topic. Two (8 percent) of the Port Nicholson Block schools declared they offered students a "choice" of topics. To conclude, eight (33 percent) of the Port Nicholson Block schools surveyed didn't offer a New Zealand history topic in their NCEA level 2 courses. Moreover, seven (29 percent) of the Port Nicholson Block schools surveyed didn't offer a topic focusing specifically on Māori content in any of their NCEA levels 1-3 history programmes. 
The teachers agreed that Māori content was often avoided because it would require Pākehā students, parents and teachers to address a contested past.

One teacher typified this view when she stated:

I've had major concerns regarding my [mainly Pākehā] students' attitudes towards New Zealand history. A lot of it has to do with their families' perspectives of New Zealand history and attitudes commonly held in the community ... For example, the Treaty of Waitangi is a major issue within New Zealand history, but a number of students think it is a 'total waste of time'. (Manning, 2008, p. 151)

Research by Kunowski (2006, pp. 134-140) may also be relevant: it, too, suggests that teachers she encountered in Christchurch schools lacked adequate content knowledge and feared "contentious" issues like the Treaty of Waitangi. Similar conclusions were drawn by Simon (1992) in her research in two Auckland schools.

All of these findings align with the observations of Adams et al. (2000, p. 131) and Smith (1990, p. 188). They indicate that Port Nicholson Block secondary schools, like schools elsewhere, reproduce the (anthropocentric) cultural capital of the dominant (Pākehā) culture. Though the Te Ātiawa interviewees and their teacher counterparts held different topic preferences, they agreed that a PBE partnership between local Te Âtiawa people and the participating schools held potential benefits.

\section{The perceived benefits of a PBE partnership}

Both groups felt that a PBE partnership between schools and "experts" nominated by local Te Ātiawa people would assist students to engage in authentic research tasks. Similarly, the research participants believed that the development of ecological literacy skills would enable students to critically reflect upon their personal understandings of concepts like identity and citizenship. Accordingly, the PBE models they envisaged aligned with the critical-pedagogy-of-place approach advocated by Gruenewald (2003) and Gruenewald and Smith (2007). Despite these similarities, there were still some significant differences in the two groups' responses to questions. 
Though the Te Ātiawa interviewees wished to strengthen local teachers' knowledge of te reo Māori (the Māori language), most teachers (eight) did not express any concern about their limited comprehension of te reo Māori. One of the Te Ātiawa interviewees (Manning, 2008, pp. 191-192) used the analogy of a Global Information System (GIS) and Global Positioning System (GPS) mapping exercise to explain why she felt history and social studies teachers should learn te reo Māori:

Having that knowledge of te reo Māori would be like adding another dimension to appreciating a series of historical layers on a [GIS] map ... By developing knowledge of te reo Māori, you're adding another level of analysis to the history of a place ... A sound knowledge of te reo Māori does give you another insight into something much deeper, something that happened, here, in this place, or that this other particular place was named after someone or something that had happened and that you may be in peril by being in that place.

Whereas the Te Âtiawa interviewees could envisage how GIS/GPS technologies could be applied in developing "holistic" digital cultural atlas activities, the teachers could not. ${ }^{10}$ The teachers I interviewed saw GIS/GPS technologies as being geographical tools only. One teacher (Manning, 2008, p. 238) said:

I've never really thought of that [GIS] as being a really significant thing. GIS is not something that naturally occurred to me as something that I would find useful for studying history. I would associate GIS technologies much more with geography ...

These were not the only barriers to a potential PBE partnership.

\section{Barriers obstructing a potential PBE partnership}

Curriculum control issues were most problematic. Though all participants shared similar concerns that aligned with Berlak and Berlak's (1981) descriptions of "control of operations" and "control of standards" dilemmas, the teachers were most concerned about "control of time" dilemmas. The Te Ātiawa interviewees, alternatively, were most concerned that teachers should not operate in isolation from local Te Ātiawa people, if teaching aspects of Te Ātiawa history. They wanted knowledgeable people, 
authorised by local Te Âtiawa people, to be collaboratively involved in the design, delivery, assessment and evaluation of courses addressing their tribe's past. The Te Ātiawa interviewees also wished to remove students, occasionally, from the allegedly "sterile" confines of classrooms and to place them in natural environs and authentic Te Ātiawa cultural settings, such as marae (meeting places). This, they reasoned, would enable students to reflect critically upon their own cultural assumptions about the interconnections between place, power, identity and citizenship.

The most pressing problem for the teachers was their inability to "control time". This finding adds weight to Scott's (1982) argument that the mechanical nature of school time is an ideological construct. The teachers repeatedly complained that they lacked time to organise field trips and/ or to teach things well. They also believed that time constraints prevented them from liaising with teachers from other "rival" subject areas within their schools or with teachers from rival schools to co-plan the sorts of interdisciplinary or holistic activities favoured by the Te Ātiawa interviewees. Because most teachers viewed themselves as being in a competition with rival subject teachers, a teacher versus teacher dichotomy existed. ${ }^{11}$

The teachers also identified the personal time cost associated with the administrative tasks of field trips as problematic. Though all of the teachers said they wanted to spend time with local Te Âtiawa people, they felt they had little time to do so, and that they should receive remuneration for any loss of "personal time". Additionally, none of the teachers felt they could resolve the challenge of reconciling the personal or particularistic and "holistic" knowledge of local Te Ātiawa people with the public or universalistic and "molecular" knowledge favoured by the majority of teachers and (allegedly) the NCEA system. The teachers also feared that if they failed to adhere to school protocols, which demand that they rely on their taurahere (nonlocal Māori) colleagues as intermediaries between their schools and local whānau, hapū (tribe/s constituting the primary political unit/s) and iwi (alliance of related hapū), they might risk doing something "wrong".

They particularly feared having an "outside" Māori group gaining control of setting "their" curriculum operations and/or standards. Though the Te Ātiawa interviewees recognised that systemic constraints would require 
some form of negotiated curriculum to be developed, they opposed taurahere teachers serving as intermediaries. They reasoned that taurahere teachers had enough work to contend with, and they preferred a "face-toface" relationship with teachers of history.

Though the Te Ātiawa interviewees preferred a more direct relationship, the teachers were uncertain about whom to contact amongst local Te Ātiawa people to establish such a relationship. Both groups of participants criticised the Ministry of Education for this impasse and for not doing more to support the strengthening of ties between the schools and local tribes. The Te Âtiawa interviewees doubted that the ministry would resource a PBE partnership underpinned by a critical pedagogy of place. They also suspected that most local schools would be unwilling to prioritise the allocation of additional resources to support such a partnership.

Most teachers, in turn, felt incapable of meeting the expectations of their Te Ātiawa counterparts, largely because they felt under immense pressure to maintain an "equal allocation of resources" stance. For example, eight of the nine teachers interviewed did not believe they possessed a budget that would allow them to purchase GIS/GPS technologies for their schools (or the funding to learn how to apply such technologies). Despite these constraints, the teachers, like their Te Ātiawa counterparts, were open to the idea of sharing curriculum control in a PBE partnership, but only if a formal agreement, in the form of a "memorandum of understanding", was developed between the schools' boards of trustees and the Wellington Tenths Trust.

Notably, all of the research participants concurred that this sort of agreement should establish the expectations of all parties and provide clear guidelines on how to manage a PBE partnership. The Te Âtiawa interviewees, like their teacher counterparts, believed that the Ministry of Education and Te Puni Kōkiri (the Ministry of Māori Development) should resource a PBE partnership between local Te Ātiawa people and the participating schools.

\section{Conclusion}

This paper concludes by drawing upon two place-based metaphors, inspired by the flora, fauna and historical geography of Te Aro (central 
Wellington city), to analyse the barriers identified by both groups. It then outlines the national policy implications of this research.

\section{The Waitangi Stream: A place-based metaphor for the research implications}

Wood (2007), via a poster, described Waitangi Park as "Wellington's newest, most exciting urban park, covering some three hectares of waterfront." She added that "the park has won international and national landscape design and architecture awards that recognise its sustainable, ecological and social attributes and its sophisticated design." As Wood (2007) recognised, the Waitangi lagoon and swamp, fed by the Waitangi stream system, was once an important food source for Taranaki whānui (tribes, like Te Ātiawa, originating from Taranaki) who inhabited the Te Aro Pā (village) and surrounding area when the Treaty of Waitangi was signed by local rangatira (chiefs) at Port Nicholson on 29 April 1840. The lagoon largely disappeared from sight following a large earthquake in 1855. The Waitangi swamp and stream system was later altered from 1859 onwards by the gradual development of an urban wastewater system that piped the stream system underground.

Today, the Waitangi Stream remains a heavily polluted and largely subterranean waterway. Little is known by the general public about the tuna that still migrate up the stormwater outfall and through the underground pipes of the Waitangi stream. Hence they remain out of sight and out of mind. Like these indomitable tuna, Te Âtiawa and other local iwi have endured major disruptions to their traditional ways of life due to the spread of British imperialism and the onset of globalisation. Just as the tuna of the Waitangi stream have journeyed thousands of nautical miles across the increasingly polluted Pacific Ocean before swimming upstream through a maze of pipes, Te Ātiawa and other local iwi have conducted their own remarkable heke (migration/s), over the centuries, overcoming many obstacles and threats to their continued existence.

These tribes' stories of place and place names in turn often refer people back to these epic journeys and events. Some of the schools studied now sit atop sites that were, and still are, of great cultural and historical 
significance to local and other iwi. The teachers I interviewed, moreover, often expressed frustration about the institutional cultures that inhibited their ability to form PBE partnerships with local iwi. Thus my formation of an hīnaki metaphor to describe the barriers that prevent them from collaborating with local tribes to address concerns like those raised by the Waitangi Tribunal (2003), outlined earlier.

\section{He hinaki tukutuku: A baited eel trap metaphor}

My hīnaki metaphor is adapted from the work of McCarthy (1994). McCarthy drew upon the analogy of a hīnaki tukutuku (baited eel trap) to illustrate similarities between the funding dilemmas confronting whare wānanga (in this instance, a Māori tertiary education institution) and the decisions facing tuna when confronted by a baited trap whilst swimming in a stream devoid of food. ${ }^{12}$ She noted $(1994$, p. 97$)$ that:

The analogy of an hīnaki is an interesting one that captures the essence of the relationship Māori share with the state. An hīnaki tukutuku is a baited eel trap that is highly effective at attracting eels. Laid on the bottom of a river or creek, the eels swim into the hinaki to feed on the delicacies provided. More importantly, however, is the fact that once the eels enter the hinaki it is difficult for them to escape. The question that the eels fail to ask is who will really be doing the eating? Beyond their own bellies being satisfied, whose bellies will they eventually satisfy? Is it possible to escape?

McCarthy's hīnaki analogy can be adapted to serve the objectives of this article because the imagery of tuna trapped in a hinnaki tukutuku describes how the teacher participants viewed their plight as professionals, all of them describing themselves as feeling "trapped" by the constraints of their schools' institutional cultures. The teachers thus resembled tuna who could not swim alongside the Te Ātiawa tuna-swimming freely outside the hinnaki-like cultures of their schools. Moreover, the entrapped tuna (teachers) recognised that they had to compete with other hungry tuna/teachers operating in rival schools or subject areas, particularly if they wished to gain access to a limited supply of bait (funding and time).

Outside the hīnaki-like cultures of the schools, the Te Ātiawa interviewees' stance resembled wary tuna which, based on prior life experiences, were 
now loath to enter local secondary schools. Rather, they were prepared to wait for these hīnaki-like school cultures to be dismantled in ways that would allow them to swim freely beside those tuna (teachers) that would otherwise choose to be free. Most of the teacher participants, however, remained entrapped by what they saw as a netting consisting of intricately woven teaching dilemmas, closely resembling Berlak and Berlak's (1981) descriptions of "control", "curriculum" and "societal" dilemmas.

This netting, like that of a tubular hīnaki, could be described as being woven tightly around the more rigid (aka vine) ribs and spines of the institutional cultures of these schools. These ribs and spines, in this instance, would symbolise the mechanical school timetables and unyielding ideological assumptions of the dominant culture regarding its ability (and right) to regulate time and space. However, the metaphor needs adjusting insofar as the teacher participants, like teachers elsewhere, can always choose to exercise agency and at least try to resist the oppressive processes of a hīnaki-like school culture (or remove themselves from it). Tuna, once trapped, cannot remove themselves so easily from such a formidable trap. In view of this, New Zealand secondary schools may well find it difficult to respond meaningfully to the new objectives of The New Zealand Curriculum, launched by the ministry in November 2007.

\section{National policy implications}

The ministry's "purpose and scope" statement (2007, p. 6) advises that the new curriculum is intended to help schools form partnerships in a manner consistent with the principle of "partnership" that is embedded within the Treaty of Waitangi: ${ }^{13}$

The New Zealand Curriculum is a statement of official policy relating to teaching and learning in English-medium New Zealand schools. Its principal function is to set the direction for student learning and to provide guidance for schools as they design and review their curriculum. A parallel document, Te Marautanga o Aotearoa, will serve the same function for Māori-medium schools ... Together the two documents will help our schools give effect to the partnership that is at the heart of our country's founding document, Te Tiriti o Waitangi/the Treaty of Waitangi. ${ }^{14}$ 
The ministry (2007, p. 8) articulated a vision for young people "who will work to create an Aotearoa New Zealand in which Māori and Pākehā recognise each other as full Treaty partners and in which all cultures are valued for the contributions they bring". It envisaged (p. 8) a curriculum that helps to develop young people who are confident in their identity, "connected" to the "land and environment" and "members of communities" that are "able to relate well to others". The ministry (p. 8) also sought a curriculum that encourages young people to be "actively involved" as "participants in a range of life contexts". None of this was inconsistent with the twin goals of a critical pedagogy of place, or the fundamentals of PBE in general.

To underpin these "vision" statements, the ministry (2007, p. 9) developed a set of curriculum "principles" designed to "embody beliefs about what is important and desirable in school curriculum-nationally and locally". It reasoned (p. 9) that "these principles put students at the centre of learning, asserting that they should experience a curriculum that engages and challenges them." Amongst these eight principles were four statements (p. 9), below, that are relevant to the goals of my research and the twin goals of a critical pedagogy of place, discussed earlier:

Treaty of Waitangi: The curriculum acknowledges the principles of the Treaty of Waitangi and the bicultural foundations of Aotearoa New Zealand. All students have the opportunity to acquire knowledge of te reo Māori me ōna tikanga [Māori language and customs].

Cultural diversity: The curriculum reflects New Zealand's diversity and values [italics added] the histories and traditions of all its peoples.

Inclusion: The curriculum is non-sexist, non-racist, and non-discriminatory; it ensures that students' identities, languages, abilities, and talents are recognised and affirmed and that their learning needs are addressed.

Community engagement: The curriculum has meaning for students, connects with their wider lives, and engages the support of their families, whānau, and communities.

When considering the synergies existing between PBE, a critical pedagogy of place and the ministry's "vision" and "principles" statements, above, 
it should be noted that the ministry also made significant statements (2007, p. 12) about what it considers constitute the "key competencies" that are the "key to learning in every learning area". The ministry (2007, p. 13) indirectly affirmed the Te Ātiawa interviewees' wishes (and PBE in general) when it stated that teachers "should" enable students to participate in "authentic" learning activities that contribute to community wellbeing:

This competency is about being actively involved in communities. Communities include family, whānau and school and those based, for example, on a common interest or culture ... Students who contribute in communities have a sense of belonging and the confidence to participate within new contexts. They understand the importance of balancing rights, roles, and responsibilities and of contributing to the quality and sustainability of social, cultural, physical and economic environments.

Although supporters of The New Zealand Curriculum (Ministry of Education, 2007) may claim that it will hardwire New Zealand content into the teaching of history via the development of a New Zealand focus through new history curriculum levels 6-8 achievement objectives, this does not guarantee that the dominant culture's (often homogeneous or universalistic) views of New Zealand history will be less prevalent, or that history teachers, who are predominantly Pākehā, will necessarily choose to incorporate Māori cultural concepts or local environmental and cultural contexts. ${ }^{15}$ While the ministry may have used a number of nonprescriptive "should" statements to frame the purpose, vision, principles and key competencies of The New Zealand Curriculum, my research suggests (pp. 81-82, 184, 304) that the ministry has not yet developed adequate policy mechanisms to ensure that New Zealand teachers of history will incorporate Māori "concepts" and "contexts" in their lesson planning.

In fact, my correspondence with the Minister of Education, Secretary for Education and other leading officials (Manning, 2008, pp. 81-82, 262266, 304-305) suggests that a laissez-faire policy framework exists that absolves the Crown from fully exercising what are arguably its Treaty of Waitangi obligations to "protect" local tribal knowledge-in accordance with the principles of "partnership" and "active protection" implicit within the Treaty, as accepted by the Crown since the 1989 Principles for 
Crown Action on the Treaty of Waitangi (Hayward, 2009). Furthermore, my research indicates that Te Ātiawa (and other local iwi), are not yet adequately enabled to "participate" in the curriculum design and delivery procedures of local schools as per the principle of "participation" implicit within both the Māori and English texts of the treaty. It might be argued, therefore, that inadequate professional development opportunities for teachers, coupled with the Crown's laissez-faire approach to the auditing of school curriculum design and delivery procedures, will result in the continued enactment of a not-so-well "hidden curriculum".

Given the inherent anthropocentricism and Eurocentricism of this enacted curriculum, I will close this article with a relevant whakatauki (proverb). This whakatauki holds resonance for those who are interested in the potential of critical pedagogies of place, and those concerned by the contributing role that history teachers have played in creating what the Waitangi Tribunal (2004, p. 740) has described as "the unsettled state of relations between Māori and Pākehā":

Ka patua te whenua i te kino,

ka ngaro te mana me te wairua mō te iwi.

Violence against the land is as destructive to

the mana [authority] and wairua [spirit]

of the people of that land as it is to the land itself.

\section{Notes}

1 In relation to the contested Port Nicholson Block area, various claims were lodged with the tribunal by different and related tribal groupings (Waitangi Tribunal, 2003, pp. 8-12). However, my research focused upon one claimant grouping (Te Ātiawa) because in 2002, as a visiting College of Education lecturer, I observed a problematic lesson about a Te Ātiawa ancestor (Te Whiti o Rongomai). This lesson illuminated a research problem worthy of further investigation.

2 The New Zealand State Services Commission (2006, p. 20) advised that the Waitangi Tribunal is a "formal, ongoing commission of inquiry to hear grievances against the Crown", run under the auspices of the New Zealand Ministry of Justice.

3 The Waitangi Tribunal (2003, p. 8) reported that the Wellington Tenths Trust was established in 1985 and "represents the interests of the beneficial owners and the beneficiaries (the families of the owners) of the Wellington Tenths [native] reserves". 


\section{Curriculum Matters 5 : 2009}

4 For example, those neighbourhoods (or communities) that border the "injured" environs of the Waiwhetū Stream in Lower Hutt, or the Waitangi Stream in Wellington city.

5 The teacher who acknowledged the racial biases of history teachers was the only teacher who did not affiliate to the New Zealand European (Pākehā/white) ethnic category.

6 Both teachers who answered in the affirmative grew up in rural and semirural settings, close to native bush.

7 These other new topics were titled: Social Welfare in the Māori World (19181998); Tangata and Whenua: Effect of Population Movement on Mãori Society (1946-1998); and Māori in a Post-Colonial World.

8 Three (13 percent) of the schools conducted special studies involving an examination of the "War in the Hutt Valley (1846)". However, Te Ātiawa chiefs were, at best, portrayed as peripheral figures in an exclusively Ngāti Toa v. Crown conflict.

9 These new topics were: Tino Rangatiratanga/Sovereignty: New Zealand and the Mãori Nation (1984-1999); Christianity and Mãori (1814-1999); and Mãori Participation in International Theatres of War in the 20th Century.

10 GIS and GPS technologies are widely used by place-based educators, particularly in digital community mapping projects, which can be used to support a plethora of community-driven initiatives.

11 This competition between subjects and schools was often attributed to the New Zealand education reforms of the 1980s under the influence of "neoliberal ideologues".

12 McCarthy (1994, p. 97) acknowledged that this analogy was first used by Turoa Royal to "describe the situation Te Whare Wānanga o Raukawa faced when it sought state funding in the mid 1990s".

13 It is also worth noting that the New Zealand Teachers' Council (2007, p. 1) produced a Code of Ethics for registered teachers which requires them to recognise that "the application of the code of ethics shall take account of the requirements of law as well as the obligation of teachers to honour the Treaty of Waitangi by paying particular attention to the rights and aspirations of Māori as tangata whenua."

14 For more information about the treaty principles, see Hayward (2009).

15 Likewise, the development of a social studies achievement objective requiring "understanding of the Treaty of Waitangi" (level 5: social studies curriculum), does not guarantee that local hapū or iwi perspectives will be incorporated.

\section{References}

Adams, P., Clark, J., Codd, J., O’Neil, A. M., Openshaw, R., \& Waitere-Ang, H. (2000). Education and society in Aotearoa New Zealand. Palmerston North: Dunmore Press. 
Berlak A., \& Berlak, H. (1981). Dilemmas of schooling: Teaching and social change. London: Methuen.

Cajete, G. (1999). Reclaiming biophilia: Lessons from indigenous peoples. In G. A. Smith \& D. R. Williams (Eds.), Ecological education in action: On weaving education, culture and the environment (pp. 189-206). New York: State University of New York Press.

Gruenewald, D. A. (2003). The best of both worlds: A critical pedagogy of place. Educational Researcher, 32(4), 3-12.

Gruenewald, D. A., \& Smith, G. A. (2007). Making room for the local. In D. A. Gruenewald \& G. A Smith (Eds.), Place-based education in the global age: Local diversity (pp. xiii-xxiii). New York: Lawrence Erlbaum.

Hayward, J. (2009). The principles of the Treaty of Waitangi (appendix). Retrieved 8 February 2009, from http://www.waitangi-tribunal.govt.nz/doclibrary/public/ Appendix(99).pdf

Kawagley, A. O., \& Barnhardt, R. (1999). Education indigenous to place: Western science meets native reality. In G. A. Smith \& D. R. Williams (Eds.), Ecological education in action: On weaving education, culture and the environment (pp. 117142). New York: State University of New York Press.

Kunowski, M. (2006). Teaching about the Treaty of Waitangi: Examining the nature of teacher knowledge and classroom practice. Unpublished doctoral thesis, Griffith University, Australia.

Manning, R. F. (2008). Place, power and pedagogy: A critical analysis of the status of Te Atiawa histories of place in Port Nicholson Block secondary schools and the possible application of place-based education models. Unpublished doctoral thesis, Victoria University of Wellington.

McCarthy, M. B. (1994). He hinaki tukutuku: Rangatiratanga, whare wānanga and the state. Unpublished master's thesis, Victoria University of Wellington.

Ministry of Education. (2001). NCEA: National Certificate of Educational Achievement: Appendix: Level 1 history achievement standards. Wellington: Author.

Ministry of Education. (2002). The National Certificate of Educational Achievement: History achievement standards professional development handbooks, levels 1 and 2 (2001-2002). Wellington: Author.

Ministry of Education. (2007). The New Zealand curriculum. Wellington: Learning Media.

New Zealand History Teachers' Association. (2005). NZHTA survey results, May 2005. Retrieved 1 June 2005, from http://www.nzhta.org.nz

New Zealand Teachers' Council. (2007). Code of ethics for registered teachers. Retrieved 5 June 2007, from http://www.teacherscouncil.govt.nz/ethics/code.stm

Scott, A. (1982). Time as ideology: From school bell to factory hooter. Delta: Policy and Practice in Education, 31, 33-45. 
Simon, J. (1992). Social studies: The cultivation of social amnesia? In G. McCulloch (Ed.), The school curriculum in New Zealand: History, theory, policy and practice (pp. 253-271). Palmerston North: Dunmore Press.

Smith, G. H. (1990). Taha Māori: Pākehā capture. In J. Codd, R. Harker, \& R. Nash (Eds.), Political issues in New Zealand education (pp. 183-197). Palmerston North: Dunmore Press.

Sobel, D. (2004). Place-based education: Connecting classrooms and communities. Great Barrington, MA: The Orion Society.

State Services Commission. (2006). Timeline of the treaty. In The Treaty of Waitangi [boxed set of five booklets]. Wellington: Author.

Waitangi Tribunal. (2003). Te Whanganui a Tara me ōna Takiwā: Report on the Wellington district. Wellington: Legislation Direct.

Waitangi Tribunal. (2004). Türanga Tangata, Türanga Whenua: The report on the Türanganui a Kiwa claims. Wellington: Legislation Direct.

Wood, N. J. (2007). Practical as well as pretty: How Waitangi Park wetlands treat stormwater and protect the harbour [poster]. Wellington: New Zealand Water and Waste Association.

\section{The author}

Richard Manning is a lecturer at the University of Canterbury College of Education where he co-ordinates the Treaty of Waitangi Education courses. He also teaches in the primary social studies and early childhood education cultural studies programmes. Richard has been a secondary school history and social studies teacher and has been employed by different government departments to develop social studies, history and treaty education resources for schools. He has also worked as a government policy analyst and researcher and as a claims inquiry facilitator for the Waitangi Tribunal. His current research interests revolve around critical pedagogies of place and PBE and their potential contribution to treaty, indigenous and history education in New Zealand and North American settings.

E-mail: richard.manning@canterbury.ac.nz 